\title{
Breeding Cowpea Vignaunguiculata l. Walp for Quality Traits
}

\author{
Tariku Simion* \\ Arbaminch Agricultural Research Center, Ethiopia
}

Submission: March 12, 2018; Published: August 27, 2018

"Corresponding author: Tariku Simion, South Agricultura Research Institute, Arbaminch Agricultural Research Center, Ethiopia, Email: trk2011smn@gmail.com

\begin{abstract}
Cowpea is truly a multifunctional crop, providing food for man and livestock and serving as a valuable and dependable revenue-generating commodity for farmers and grain traders. Cowpea is of major importance to the livelihoods of millions of people in less developed countries of the tropics. It is consumed in many forms. Young leaves, green pods, and green seeds are used as vegetables, and dry seeds are used in various food preparations with $25 \%$ protein (on dry-weight basis) in its seeds and tender leaves, cowpea is a major source of protein, minerals, and vitamins in the daily diets in Africa, and thus it positively influences the health of men, women and children. The bulk of the diet of the rural and urban poor in Africa consists of starchy food made from cassava, yam, plantain and banana, millet, sorghum, and maize. The addition of even a small amount of cowpea ensures a nutritional balance and enhances the protein quality by the synergistic effect of high protein and high lysine from cowpea and high methionine and high energy from the starchy foods. Trading fresh produce and processed cowpea foods and snacks provides rural and urban women opportunity for earning cash income. A good knowledge of crop taxonomy contributes to an efficient use of germplasm for hybridization in the breeding programs. In addition, the results of hybridizations and cross compatibilities provide the basis for improving plant classification. Large and diverse cowpea germplasm collections are available to the researchers around the world, especially in Africa, to exploit the valuable genes to improve cowpea cultivars.
\end{abstract}

Keywords: Synergistic effect; Quality and Hybridizations

\section{Introduction}

Cowpea [Vignaunguiculata (L.) Walp.] is one of the most important food and forage legumes in the semi-arid tropics that include parts of Asia, Africa, Southern Europe, Southern United States, and Central and South America [1]. It is truly a multifunctional crop, providing food for man and livestock and serving as a valuable and dependable revenue-generating commodity for farmers and grain traders [2]. The cowpea plant is a herbaceous, warm-season annual requiring temperatures of at least $18{ }^{\circ} \mathrm{C}$ throughout all stages of its development and having an optimal growing temperature of about $28{ }^{\circ} \mathrm{C}$ [3]. Seeds of cultivated cowpea types weigh between $80 \mathrm{mg}$ and $320 \mathrm{mg}$ and range in shape from round to kidney-shaped. The seed pods contain between eight and 18 seeds per pod and are cylindrical and curved or straight. The seed coat varies in texture (e.g., smooth, rough, or wrinkled), color (e.g., white, cream, green, buff, red, brown, black), and uniformity (e.g., solid, speckled, or patterned). Seeds of the most well-known cowpea types, such as "blackeye pea" and "pinkeye," are white with a round irregularly shaped black or red pigmented area encircling the hilum that gives the seed the appearance of an eye. Cowpea is primarily a short-day plant or in some instances, day-neutral [4]. Floral bud initiation and development is sensitive to photoperiod in many cowpea accessions, and in some genotypes the degree of photoperiod sensitivity (i.e., the extent of delay in flowering) is influenced by temperature [5]. In West Africa, selection for differing degrees of photosensitivity or differences in extent of juvenile growth has occurred in different climatic zones resulting in genotypes where pod ripening occurs at the end of the rainy season in a given locale, regardless of planting date that often varies due to the variable onset of wet seasons [6]. This attribute allows pods to escape damage from excessive moisture and pathogens.

A drought tolerant and warm weather crop, cowpea is well adapted to the drier regions of the tropics, where other food legumes do not perform well. It also has the unique ability to fix atmospheric nitrogen through its nodules and it grows well even in poor soils with more than $85 \%$ sand and with less than $0.2 \%$ organic matter and low levels of phosphorus [7]. In addition, it is shade tolerant and therefore, compatible as an intercrop with maize, millet, sorghum, sugarcane, and cotton as well as with several plantation crops and thus it forms a valuable component of the traditional cropping systems [8]. Coupled with these attributes, its quick growth and rapid ground cover checks soil erosion and in-situ decay of its roots, and nitrogen-rich residue improves soil fertility and structure, which together have made cowpea an important component of subsistence agriculture, particularly in the dry savannas of Sub-Saharan Africa [8]. Nigeria is the largest producer and consumer of cowpea, with about 5 
million ha area and about 2.4 million tons produced annually. Niger Republic is the next largest producer, with 3 million ha and more than 350,000 tons produced. Northeast Brazil grows about 1.5 million ha of cowpea, with about 491,558 tons produced, which provides food to about 25 million people. In the southern U.S., about 40,000 ha of cowpea is grown, with an estimated 45,000 tons annual production of dry cowpea seed and a large amount of frozen green cowpeas. India is the largest cowpea producer in Asia, and together with Bangladesh, Indonesia, Myanmar, Nepal, Sri Lanka, Pakistan, Philippines, Thailand, and other far eastern countries, there may be more than 1.5 million ha under cowpea in Asia [6].

Cowpea is of major importance to the livelihoods of millions of people in less developed countries of the tropics. It is consumed in many forms. Young leaves, green pods, and green seeds are used as vegetables, and dry seeds are used in various food preparations [9]. With 25\% protein (on dry-weight basis) in its seeds and tender leaves [10], cowpea is a major source of protein, minerals, and vitamins in the daily diets in Africa, and thus it positively influences the health of men, women and children [11]. The bulk of the diet of the rural and urban poor in Africa consists of starchy food made from cassava, yam, plantain and banana, millet, sorghum, and maize. The addition of even a small amount of cowpea ensures a nutritional balance and enhances the protein quality by the synergistic effect of high protein and high lysine from cowpea and high methionine and high energy from the starchy foods. Trading fresh produce and processed cowpea foods and snacks provides rural and urban women opportunity for earning cash income. Cowpea is equally important as nutritious fodder for livestock, particularly in the dry savannas of West Africa [12] reviewed the literature on the use of cowpea haulms as fodder in different parts of the world. In West Africa, the mature cowpea pods are harvested, and the haulms are cut while still green and rolled into small bundles containing the leaves and vines. These bundles are stored on rooftops or on tree forks for use and for sale as "Harawa" (feed supplement) in the dry season, making cowpea haulms the key factor for crop-livestock systems [13]. On the dry-weight basis, the price of cowpea haulms ranges between 50 and $80 \%$ of the grain price, and therefore, haulms constitute an important source of income. Just like cowpea grains and leaves, the nutritive value of cowpea haulms is also very high. The crude protein content ranges from 13 to $17 \%$ in cowpea haulms, with high digestibility and low fiber [14], and thus, cowpea fodder is a good protein supplement to cereal stalks for feeding livestock. The objective of this paper is to review the effort that has been made to improve cowpea for quality traits.

\section{Origin and distribution}

Major diversity in cowpea is found in Asia and Africa, but the precise origin of cowpea has been a matter of speculation and discussion for many years. Early observations showed that cowpeas in Asia were divers and morphologically different from those in Africa. Therefore, both Asia and Africa were thought to be independent centers of origin of cowpea. However, in the absence of wild cowpeas in Asia as possible progenitors, an Asian center of origin has recently been questioned. All the current evidence suggests that cowpea originated in Southern Africa, although it is difficult to ascertain where in Africa the crop was first domesticated. Several centers of domestication have been suggested, such as Ethiopia, Central Africa, South Africa, and West Africa.

Suggested that cowpea probably moved from Eastern Africa to India before $150 \mathrm{BC}$, to West Asia and Europe about $300 \mathrm{BC}$, and to the Americas in 1500 AD. Since Western Asia and Europe do not have desired climatic conditions for cowpea, not as much variability and selection occurred as in South Asia and South East Asia, where small seeded and vegetable cowpeas were selected. The wild cowpeas with very small seeds were probably distributed by birds in East and West Africa long before the Christian Era, and therefore, there exist great diversity and secondary wild forms there. Selections for larger seeds and better growth habits from natural variants in wild cowpeas by humans must have led to diverse cult groups and their domestication in Asia and in Africa. Using chloroplast DNA polymorphism, suggested Nigeria to be the center of domestication in West Africa. In contrast, studies based on analysis of amplified fragment length polymorphism (AFLP) profiles led Coulibaly et al. [14] to propose domestication in northeastern Africa.

Currently, the wild cowpea, Vigna unguiculata ssp. unguiculata var. spontanea, is thought to be the likely progenitor of cultivated cowpea [15]. Using a new set of chloroplast DNA primers evaluated 54 domesticated cowpea accessions and 130 accessions from the wild progenitor [14]. They confirmed the earlier observation of [16] that domesticated accessions, including primitive landraces from cultivar groups biflora and textilis, are missing the BamHI restriction site in chloroplast DNA, suggesting that this mutation occurred prior to domestication. However, 40 var. spontanea accessions distributed from Senegal to Tanzania and South Africa showed the alternative haplotype. Whereas this marker could not be used to identify a precise center of origin, it's very high frequency in West Africa was interpreted as a result of either genetic swamping of the wild/weedy gene pool by the domesticated cowpea gene pool or as the result of domestication by ethnic groups focusing primarily on cowpea as fodder [17]. It is likely that the cowpea was first introduced to India during the Neolithic period [18] and was certainly there before the Christian era, since it has a Sanskrit name in writings dated to 150 BC [19]. It is at that point that human selection led to it being modified to a form different from that present in Africa. Cowpea probably moved to West Asia and parts of Europe between 800 and 300 BC.

\section{Taxonomy}

Cowpea is a Dicotyledonous belonging to the order Fabaceae, subfamily Faboideae (Syn. Papillionoideae), tribe Phaseoleae, subtribe Phaseolinae, genus Vigna, and section Catiang [16]. Vigna is a pantropical and highly variable genus with several species, the number varying from 84 to 184 [20]. The genus Vigna has been subdivided into seven subgenera: Vigna, Sigmoidotropis, 
Plectotropis, Macrophynca, Ceratotropis, The subgenus Vigna has been futher subdivided into six sections: Vigna, Comosae, Macrodontae, Reticulatae, Liebrechtsia, and Catiang. Cowpea belongs to section Catiang, which, according to Verdcourt [21], consisted of five species, $V$. unguiculata, $V$. pubescence, $V$. augustifoliolata, $V$. tenuis, and V. nervosa. However, [22] reduced these to only two species, $V$. unguiculata and $V$. nervosa and classified the others into subspecies of $V$. unguiculata.

\section{Gene pool}

A good knowledge of crop taxonomy contributes to an efficient use of germplasm for hybridization in the breeding programs. In addition, the results of hybridizations and cross compatibilities provide the basis for improving plant classification. This approach has permitted grouping of the germplasm available for hybridization into primary, secondary, or tertiary gene pools [23]. The primary gene pool includes both the cultivated and the wild forms, which are easily hybridized. The secondary and the tertiary gene pools comprise all the species among which gene flow is possible through interspecific hybridization but with increasing degrees of difficulty. The boundary between secondary and tertiary gene pools may not always be well defined. In general, when the cross is successful but the F1 hybrid is less fertile or presents moderate structural heterology, the donor species will then be considered to belong to the secondary gene pool. Thus, the secondary gene pool comprises other species that are relatives of the crop and are suitable for interspecific hybridization. Thus, the tertiary gene pool involves still greater barriers to hybridization compared to the secondary gene pool, embracing species that display either unviable or sterile hybrids with the cultivated plant and do not permit gene flow by conventional methods of introgression.

\section{Germplasm resource}

The significance of cowpea germplasm collection, evaluation, preservation, and use for improving cowpea cultigens has been reviewed Prior to 1967, a few national agricultural research programs, such as Nigeria, Senegal, Tanzania, and Uganda in Africa; India in Asia; and the U.S. in the Americas, had some level of cowpea improvement program, and they were maintaining some collection of cowpea germplasm. However, with the establishment of the International Institute of Tropical Agriculture (IITA) in 1967 and its global mandate for the improvement of cowpea, IITA has made a collection of cowpea germplasm exceeding 15,100 accessions of cultivated varieties drawn from more than 100 countries and 560 accessions of wild cowpeas. The germplasm lines maintained at IITA have been numbered as TVv (Tropical $V$. unguiculata, i.e., $\mathrm{TVu}^{-1}, \mathrm{TVu}^{-2}$, etc.). These have been characterized and evaluated for desirable traits and are being preserved and used in the breeding program at IITA, as well as in national breeding programs [24]. These large and diverse cowpea germplasm collections are available to all the cowpea researchers around the world, especially in Africa, to exploit the valuable genes to improve cowpea cultivars

\section{Economic, agronomic and social importance}

Cow pea [Vignaunguiculata (L). Walp] [25] is known by a variety of names worldwide, with cowpea being among the most prevalent in the literature. In the English-speaking parts of Africa, it is known as cowpea where as in the Francophone regions of Africa, the name "niébé" is most often used. Local names for cowpea also include "seub" and "niao" in Senegal, "wake" in Nigeria, and "luba hilu" in the Sudan. In the United States, it is typically referred to as blackeye beans, blackeye peas, and southern peas. On the Indian subcontinent, it is called "lobia" and in Brazil it is "caupi." The seed, or grain as it is sometimes referred to, is the most important part of the cowpea plant for human consumption. The seeds are most often harvested and dried for storage and consumption at a later time, either after cooking whole or after being milled like a flour product such as cowpea, plays a critical role in the lives of millions of people in the developing world, providing them a major source of dietary protein that nutritionally complements low-protein cereal and tuber crop staples [26].

The nutritional profile of cowpea grain is similar to that of other pulses with a relatively low-fat content and a total protein content that is two- to fourfold higher than cereal and tuber crops. Similar to other pulses, the storage proteins in cowpea seeds are rich in the amino acids lysine and tryptophan when compared to cereal grains, but low in methionine and cystiene when compared to animal proteins. Total seed protein content ranges from $23 \%$ to $32 \%$ of seed weight [19]. Cowpea seeds are also a rich source of minerals and vitamins and among plants have one of the highest contents of folic acid, a B vitamin necessary during pregnancy to prevent birth defects in the brain and spine. In the southeastern parts of the United States, portions of West Africa, Asia, and in the Caribbean, consuming fresh seeds and green pods is preferred to the cooked dry seeds. In many parts of Africa and Asia, in addition to the seeds, the fresh or dried leaves are also consumed as a side dish or as part of a stew and provide significant nutritional value. In addition to human consumption, cowpea leaves and stems (stover) are also an important source of high-quality hay for livestock feed [11]. Cowpea fodder plays a particularly critical role in feeding animals during the dry season in many parts of West Africa. Although protease inhibitors have been found in the seed, the use of cowpea grain does not apparently present any serious nutritional problems in animal nutrition and has been used an alternative to other costlier grain protein sources of animal feed. Dry grain production is the only commodity of cowpea for which production estimates are generated on a worldwide basis. According to the United Nations Food and Agricultural Organization (FAO), approximately 4 million metric tons of dry cowpea grain are produced annually on about 10 million ha worldwide. About $70 \%$ of cowpea production occurs in the drier Savanna and Sahelian zones of West and Central Africa, where the crop is usually grown as an intercrop with pearl millet (Pennisetum glaucum) or sorghum (Sorghum bicolor). In these regions, cowpea is less frequently planted in monoculture or intercropped with maize (Zea mays), cassava (Manihot esculenta), or cotton 
(Gossypium sp.) [27]. Other important cowpea production areas include the lower elevation areas of eastern and southern Africa, low elevation areas in South America (particularly in Peru and northeastern Brazil), parts of India, and the southeastern and southwestern regions of North America.

Nigeria is the largest producer and consumer of cowpea grain with approximately 5 million ha under cultivation with an annual yield estimate at 2.0 million metric tons. After Nigeria, Niger and Brazil are the next largest producers with annual yields estimated at $650,000 \mathrm{mt}$ and $490,000 \mathrm{mt}$, respectively. Commercial trading of dry cowpea grain and hay are particularly important to the local and regional economies of West Africa. Most of the cowpea grain sold at large commercial markets in large urban centers of coastal West Africa is produced further inland where climates are drier and favorable to production of high-quality grain. Compared to other legumes, cowpea is known to have good adaptation to high temperatures and resistance to drought stress [28]. For example, Hall [22] reported cowpea grain yields of as much as $1000 \mathrm{~kg}$ ha $^{-1}$ of dry grain in a Sahelian environment with low humidity and only $181 \mathrm{~mm}$ of rainfall. At present, few other legume crop species are capable of producing significant quantities of grain under these conditions. Cowpea is also a valuable component of farming systems in areas where soil fertility is limiting. This is because cowpea has a high rate of nitrogen fixation forms effective symbiosis with mycorrhizae [20].

In addition, well-adapted, early maturing cowpea varieties capable of producing seed in as few as 55 days after planting often provide farmers with the first source of food from the current harvest sooner than any other crop. In the developing world where soil infertility is high, rainfall is limiting, and most of the cowpea is grown without the use of fertilizers and plant protection measures (i.e., pesticides or herbicides), a wide variety of biotic and abiotic constraints also limit growth and severely limit yield. While cowpea is inherently more drought-tolerant than other crops, water availability is still among the most significant abiotic constraints to growth and yield. Erratic rainfall at the beginning and towards the end of the rainy season adversely affects plant growth and flowering resulting in a substantial reduction in grain yield and total biomass production. The use of early maturing cultivars helps farmers escape the effects of a late season drought, but plants exposed to intermittent moisture stress during the vegetative or reproductive stages will perform very poorly.

Anti-nutritional factors: Anti-nutritional factors are plant's secondary metabolites which act to reduce food nutrient utilization [29]. Anti-nutritional factors affect susceptibility of grains to insect attack [30]. However, the presence of antinutritional factors commonly found in legumes is a major factor limiting the wider food use of these essential tropical plants [31]. For instance, phytic acid and Oxalic acid reduce mineral bioavailability that leads to various mineral deficiency diseases e.g. anemia [32] or form deleterious complexes with metal ions e.g. calcium-oxalate that leads to renal damage [33]. Plants contain thousands of compounds which, depending upon the situations, can have beneficial or deleterious effects on organisms consuming them. These compounds, with the exception of nutrients, are referred to as 'allelochemicals'. Anti-nutrients have been shown to possess pharmacological values. Tannins for examples, possess anticancer and cytotoxin properties. Tannins are complex polyphenolic found widely in the plant kingdom. Phytic acid's mineral binding properties are believed to prevent colon cancer by reducing oxidative stress in the lumen of the intestinal tract. The chelating effect may serve to prevent, inhibit, or even cure some cancers by depriving those cells of the minerals (especially iron) they need to reproduce. Ant-nutrients are found in almost all foods. However, their levels are reduced in most common food crops probably through selection during the process of domestication. Nevertheless, the large fraction of human diets that come from these crops raise concern about the possible effects of anti-nutrients on human health. The possibility now exists to eliminate anti-nutrients entirely using genetic engineering, but since these compounds may also have beneficial effects, such genetic modifications could make the food crops more nutritious without the capacity to improve other aspects of human health [34].

Phytic and oxalic acids [35] are among the major antinutrients present in plant protein sources both being antiminerals. Phytic acid, also known as inositol hexakisphosphate (IP6), or phytate when in salt form is the principal storage form of phosphorus in many plant tissues, especially bran and seeds [36]. It is not digestible to humans or non-ruminant animals, because these animals lack the digestive enzyme (phytase) required to remove phosphate from the inositol in the phytate molecule. On the other hand, ruminants readily digest phytate because of the phytase produced by microorganisms in their rumen. Phytate is well documented to block absorption of not only phosphorus, but also of other minerals such as calcium, magnesium, iron and zinc [37]. Thus, foods high in these anti-nutrients should be adequately processed to make them wholesome for consumers. In ruminants however, dietary oxalic acid can be degraded by rumen microbes into $\mathrm{CO}_{2}$ and formic acid. The amount of ant-nutrients in food crops is highly variable and depends on factors including environmental condition, use of high-phosphate fertilizers in cultivation and genotypic variation.

General breeding strategies: Most cowpea breeders employ backcross, pedigree, or bulk breeding methods to handle segregating populations because cowpea is a self-pollinating species and varieties are pure lines. Higher grain yields and improved grain quality are the primary breeding objectives of nearly all programs. In addition, most breeders seek to incorporate a wide range of abiotic and biotic stress resistance/ tolerance characters. The constraints that direct individual breeding programs at the local and national program levels depend on the major diseases and pests encountered in their target environments. The general strategy of most breeding programs is to develop a range of high yielding cowpea varieties adapted to different agro ecological zones that possess regionally preferred traits for plant type, growth habit, days to maturity, and 
seed type. In general, the focus is on the development of extraearly maturing (60-70 days) and medium maturing (75-90 days), non-photosensitive lines with good grain quality and potential for dual-purpose use (i.e., food and fodder), either for use as a sole crop and as an intercrop in multiple cropping systems. Other traits targeted include resistance to major diseases, insect pests, and parasitic plants (S. gesnerioides and A. vogelii), tolerance to drought, heat, acidity and low fertility, and seed types with high protein content and low cooking time. For example, new extraearly cowpea varieties have been developed that have erect plant type, early maturity and resistance to major pests, and are capable of yields up to 2.5 tons ha ${ }^{-1}$ within 60 days compared to less than 1 ton/ha of the local varieties, which mature in 100 to 140 days. Similarly, a number of medium maturing, dual-purpose cowpea varieties have been developed which yield over 2.5 tons ha ${ }^{-1}$ grain and over 3.0tons $\mathrm{ha}^{-1}$ fodder in 75-80days. In recent years, over 40 improved cowpea varieties have been released in 60 countries covering Africa, Asia, and Central and South America.

Breeding for improved nutritional quality: Cowpea is a major source of protein, minerals, and vitamins in the daily diets of the rural and urban masses in the tropics, particularly in West and Central Africa where it complements the starchy food prepared from cassava, yam, sorghum, millet, and maize. Systematic efforts have just begun at IITA and a few other institutions to develop improved cowpea varieties with enhanced levels of protein and minerals combined with faster cooking and acceptable taste. Singh screened 52 improved and local cowpea varieties to estimate the extent of genetic variability for protein, fat, and minerals. On a fresh weight basis (about 10\% moisture), the protein content ranged from 20 to $26 \%$ [38], fat content from 0.36 to $3.34 \%$, iron content from 56 to $95.8 \mathrm{ppm}$, and manganese content from 5 to 18ppm. The improved cowpea varieties IT89KD-245, IT89KD-288, and IT97K-499-35 had the highest protein content (26\%), whereas the local varieties like Kanannado, Bauchi early, and Bausse local had the lowest protein content (21 to 22\%). One local variety, IAR 1696, had high protein content (24.78\%) and high fat content (3.28\%), as well as high iron content (81.55ppm). Similarly, an improved variety, IT95K-686-2, had high protein content $(25 \%)$, high fat content $(3.3 \%)$, and high iron content (76.50ppm). Appropriate crosses have been made to study the inheritance of protein, fat, and iron contents and to initiate a breeding program for improving these quality traits. The seed hardness was positively correlated with calcium content ( $\mathrm{r}=0.70$ ), iron content $(r=0.29)$, and zinc content $(r=0.40)$. High amounts of calcium, iron, and zinc are desirable from a nutritional standpoint. However, they may increase the seed hardness and cooking time. Soaking of the seeds before cooking reduces cooking time. Seed hardness was positively correlated with cooking time. There have been earlier reports on the extent of genetic variability for quality traits in cowpea. [39] reported high methionine content in Tvu 2093 and Bush Sitao (3.24-3.4mg/g) dry seeds compared to 2.75$2.88 \mathrm{mg} / \mathrm{g}$ seeds of the check variety, G-81-1. del. and observed the highest trypsin inhibitor activity in winged bean and lima bean and the lowest activity in mungbean and rice bean, whereas the trypsin inhibitor values for cowpea were intermediate [40].

\section{Summary}

Cowpea is one of the most important food and forage legumes in the semi-arid tropics that include parts of Asia, Africa, Southern Europe, Southern United States, and Central and South America. It is truly a multifunctional crop, providing food for man and livestock and serving as a valuable and dependable revenue-generating commodity for farmers and grain traders. A drought tolerant and warm weather crop, cowpea is well adapted to the drier regions of the tropics, where other food legumes do not perform well. It also has the unique ability to fix atmospheric nitrogen through its nodules, and it grows well even in poor soils with more than $85 \%$ sand and with less than $0.2 \%$ organic matter and low levels of phosphorus. Cowpea is equally important as nutritious fodder for livestock, particularly in the dry savannas of West Africa. Cowpea remains to a large extent an underexploited crop where relatively large genetic gains can be made with only modest investments in both applied plant breeding and molecular genetics. Because it is grown mostly by poor farmers in developing countries it has received relatively little attention from a research standpoint.

\section{References}

1. Singh BB (2005) Cowpea [Vigna unguiculata (L.) Walp. In: Singh RJ, Jauhar PP (Ed) Genetic Resources, Chromosome Engineering and Crop Improvement. CRC Press, Boc Raton, USA, pp. 117-162.

2. Singh S, Kundu SS, Negi AS, Singh PN (2006) Cowpea (Vigna unguiculata) legume grains as protein source in the ration of growing sheep. Small Ruminant Res 64(3): 247-254.

3. Craufurd PQ, Summerfield RJ, Ell RH, Roberts EH (2010) Photoperiod, temperature and the growth and development of cowpea (Vigna unguiculata). In: Singh BB, et al. (Eds.) Advances in Cowpea Research. Copublication Intl Inst Tropical Agric (IITA) and Japan Intl Res Center Agric Sci (JIRCAS). Sayce, Devon, UK.

4. Ehlers JD, Hall AE (2011) Genotypic classification of cowpea based on responses to heat and Photoperiod. Acsess 36(3): 673-679.

5. Wein HC, Summerfield RJ (2008) Adaptation of cowpeas in West Africa: Effects of photoperiod and temperature responses in cultivars of diverse origin. In: Summerfield RJ \& Bunting AH (Eds.) In: Advances in legume science 14: 405-417.

6. Steele WM, Mehra KL (2009) Structure, evolution and adaptation to farming systems and environments in Vigna. In: Summerfield RJ, Bunting AH (eds) Advances in Legume Science. Royal Botanic Gardens, Kew, UK, pp. 393-404

7. Sanginga N, Dashiell KE, Diels J, Vanlauwe B, Lyasse O, et al. (2009) Sustainable resource management coupled to resilient germplasm to provide new intensive cereal-grain-legume- livestock systems in the dry savanna. Agric Ecosyst Environ 100(2-3): 305-314

8. Purseglove JW (2006) Tropical Crops - Dicotyledons. Longman, UK 163(3871): 1050-1051.

9. Fatokun CA, Menancio Hautea DI, Danesh D, Young ND (1992) Evidence for orthologus seed weight genes in cowpea and mung bean based on RFLP mapping. Genetics 132(3): 841-846.

10. Carsky RJ, Vanlauwe B, Lyasse $O$ (2010) Cowpea rotation as a resource management technology for cereal-based systems in the savannas of West Africa. In: Fatokun CA, et al. (Eds) Challenges and Opportunities 
for Enhancing Sustainable Cowpea Production. International Institute of Tropical Agriculture, Ibadan, Nigeria, pp. 252-266.

11. Nielson SS, Brandt WE, Singh BB (2010) Genetic variability for nutritional composition and cooking time of improved cowpea lines. Crop Sci 33(2): 469-472.

12. Bressani R (2011) Nutritive value of cowpea. In: Singh SR, Rachie KO (eds) Cowpea Research, Production and Utilization. John Wiley and Sons, Ltd., Chichester, NY, USA, pp. 353-359.

13. Coulibaly S, Pasquet RS, Papa R, Gepts P (2010) AFLP analysis of the phenetic organization and genetic diversity of cowpea [Vigna unguiculata (L)Walp.] reveals extensive gene flow between wild and domesticated types. Theor Appl Genet 104(2): 258-266.

14. Tarawali SA, Singh BB, Peters M, Blade SF (2009) Cowpea haulms as fodder. In: Singh BB, et al. (Eds), Advances in Cowpea Research. Copublication Intl Inst Tropical Agric (IITA) and Japan Intl Res Center Agric Sci (JIRCAS). Sayce, Devon, UK, pp. 313-325.

15. Singh BB (2009) Cowpea [Vigna unguiculata (L.) Walp. Genetic Resources, Chromosome Engineering and Crop Improvement.

16. Baudoin JP, Maréchal R (2011) Genetic diversity in Vigna. In: Singh SR, Rachie KO (eds) Cowpea Research, Production and Utilization. John Wiley and Sons, Ltd., Chichester, England, UK.

17. Feleke Y, Pasquet RS, Gepts P (2006) Development of PCR-based chloroplast DNA markers that characterize domesticated cowpea (Vigna unguiculata ssp unguiculata var unguicalata) and highlight its crop-weed complex. Plant Syst Evol 262: 75-87.

18. Vaillancourt RE,Weeden NF, Barnard JD (2009) Isozyme diversity in the cowpea species complex. Crop Sci 33(3): 606-613.

19. Tosti N, Negri V (2008) Efficiency of three PCR-based markers in assessing genetic variation among cowpea (Vigna unguiculata ssp. unguiculata) landraces. Genome 45(2): 656-660.

20. Timko MP, Ehlers JD, Roberts PA (2007) Cowpea. Genome Mapping and Molecular Breeding in Plants, In: Kole C (Ed) Volume 3, Pulses, Sugar and Tuber Crops, Springer Verlag, Berlin Heidelberg Sci and Edu, pp. 49-67.

21. Steele WM, Mehra KL (2009) Structure, evolution and adaptation to farming systems and environments in Vigna. In: Summerfield RJ, Bunting AH (eds) Adv in Legume Sci. Royal Botanic Gardens, UK: 393404

22. Verdcourt B (1970) Studies of the Leguminosae-Papilionoideae for 'Flora of Tropical East Africa': IV. Kew Bull 24(3): 507-569.

23. Maréchal R, Mascherpa JM, Stainer F (1978) Etude taxonomique d'un group complexe d'especes des genres Phaseolus et Vigna (Papillionaceae) sur la base de donnees morphologiques et polliniques traitees par l'analyse informatique. Boissiera 28: 1-273.

24. Singh S, Kundu SS, Negi AS, Singh PN (2006) Cowpea (Vigna unguiculata) legume grains as protein source in the ration of growing sheep. Small Ruminant Res 64(3): 247-254.
25. Phillips RD, McWatters KH, Chinannan MS, Hung Y, Beuchat LR, et al. (2003) Utilization of cowpeas for human food. Field Crops Res 82:193213 photoperiod. Crop Sci 82: 193-213.

26. Hall AE, Singh BB, Ehlers JD (2011) Cowpea breeding. Plant Breed Rev 15: 215-274.

27. Ng NQ, Marechal R (2010) Cowpea taxonomy, origin and germplasm. In: Singh SR, Rachie KO (Eds.), Cowpea Research, Production and Utilization. John Wiley and Sons, Ltd, NY, USA, pp. 11-21.

28. Nielson SS, Ohler TA, Mitchell CA (1997) Cowpea leaves for human consumption: production, utilization, and nutrient composition. In: Singh BB, et al. (Eds.), Advances in Cowpea Research. Copublication Intl Inst Tropical Agric (IITA) and Japan Intl Res Center Agric Sci (JIRCAS). Sayce, Devon, UK, pp. 326-332.

29. Hannah LC, Ferrero J, Dessauer DW (1976) High methionine lines of cowpea, Tropical Grain Legume Bulletin (Nigeria). 4(9).

30. Pant KC, Chandel KPS, Joshi BS (2007) Analysis of diversity in Indian cowpea genetic resources. SABRO J 14: 103-111.

31. Hall AE, Singh BB, Ehlers JD (2011) Cowpea breeding. Plant Breed Rev 15: 215-274.

32. Soetan KO (2008) Pharmacological and other beneficial effects of antinutritional factors in plants -A review. African Journal of Biotechnology 7(25): 4713-4721.

33. Langyintuo AS, Lowenberg DBJ, Faye M, Lamber D, Ibro G, et al. (2003) Cowpea supply and demand in West Africa. Field Crops Res 82(2-3): 215-231.

34. Harborne JB (1989) Biosynthesis and function of anti-nutritional factors in plants. Aspects of Applied Biology, UK 19: 21-28.

35. Liener LE, Kakade ML (1980) Protease inhibitors. In: The lectins: Properties, functions, and applications in biology and medicine. Academic Press, New York, USA, pp. 527-552.

36. Guthre DG, Picciano MF (1995) Human nutrition. (1 $1^{\text {st }}$ edn). WCB/ McGraw-Hill, New York, USA, pp. 43-44.

37. Shukkur MF, Abdul SE, Karthik HS, Ramasamy S, Nachiappa GR, et al. (2006) Oxalate mediated nephronal impairment and its inhibition by c-phycocyanin: a study on urolithic rats. Mol Cell Biochem 284(1-2): 95-101.

38. Klopfenstein TJ, Angel R, Cromwell G, Erickson GE, Fox DG, et al. (2002) Animal diet modification to decrease thepotential for nitrogen and phosphorus pollution. Council for Agricultural Science and Technology 21: 175-188.

39. Gomathinayagam P, Ram SG, Rathnaswanmy R, Ramaswamy NM (1998) Interspecific hybridization between Vigna unguiculata (L) Walp and V. vexillata (L) A. Rich, through in vitro embryo culture. Euphytica 102(2): 203-209.

40. Barone A, del Guidice A, Ng NQ (1992) Barriers to interspecific hybridization in $V$. unguiculata and $V$. vexillata. Sexual Plant Reproduction 5(3): 195-200. 


\section{Your next submission with Juniper Publishers} will reach you the below assets

- Quality Editorial service

- Swift Peer Review

- Reprints availability

- E-prints Service

- Manuscript Podcast for convenient understanding

- Global attainment for your research

- Manuscript accessibility in different formats ( Pdf, E-pub, Full Text, Audio)

- Unceasing customer service

Track the below URL for one-step submission https://juniperpublishers.com/online-submission.php 